Journal of Scientific Perspectives

Volume 3, Issue 2, Year 2019, pp. 85-98

E - ISSN: 2587-3008

URL: http://ratingacademy.com.tr/ojs/index.php/jsp

DOI: https://doi.org/10.26900/jsp.3.010

Research Article

\title{
THE EFFECT OF COMBINATION OF BORIC ACID AND LITHIUM CARBONATE ON SINTERING AND MICROSTRUCTURE IN SINGLE FIRING WALL TILE
}

\author{
Savaş ELMAS* \& İsmail TARHAN** \\ * Res. Assist., Çanakkale Onsekiz Mart University, Faculty of Fine Arts, Ceramic and Glass \\ Department, Çanakkale,TURKEY, E-mail: savaselmas@comu.edu.tr \\ ORCID ID: https://orcid.org/0000-0003-2913-0303 \\ ** Prof. Dr., Çanakkale Onsekiz Mart University, Faculty of Arts and Sciences, Physics,Çanakkale, \\ TURKEY, E-mail: ismailtarhan@comu.edu.tr \\ ORCID ID: https://orcid.org/0000-0001-6156-0827
}

Received: 3 March 2019; Accepted: 14 April 2019

\begin{abstract}
The aim of this study was to determine the effect of boric acid and lithium carbonate on microstructure and sintering characteristics of wall tile after firing. Amount of Li2 (CO3) (0.1-0.3-0.60.9-1.2-4 wt.\%) were added in wall tile corresponding to each constant amount of added of $\mathrm{H} 3 \mathrm{BO} 3$ (0.1-0.3-0.6-0.9-1.2-2 wt.\%). All samples were fired in 1135 OC 35 minutes in an industrial fast firing kiln. Dry strength, fired strength, water absorption and colorimeter values of all samples were determined after firing. Scanning electron microscope (SEM), $x$-ray diffraction (XRD) analysis, optical dilatometer measurements were performed in order to determine the microstructure and melting temperature for prescribed purpose (1-2-7-8-11-32-37). Standard (1) and alternative (8) receipe's thermogravimetric and diferantial thermal analyses were performed. $37(2 \% \mathrm{H3BO} 3+4 \% \mathrm{Li} 2$ (CO3) recipe's sintering starting temperature was 984 OC. In the recipe $8(0.3 \% \mathrm{H} 3 \mathrm{BO} 3+0.1 \% \mathrm{Li2}$ (CO3) is an alternative to the standard wall tile, which can be used with higher strength values.
\end{abstract}

Keywords: Flux, Sintering, Microstructure, Boric acid, Litium carbonate, Wall tile

\section{INTRODUCTION}

Under the conditions of increasing competition with globalization, the price of the product is one of the factors considered as a priority for the customers. Reducing the sintering temperature and improving the microstructure are important issues today. The microstructure affects the physical properties desired from the product. The largest energy consumption in the ceramic industry is in firing. 55\% of the thermal energy is used here. The approximate energy consumption in ceramic tile production is $4608 \mathrm{kj} / \mathrm{kg}$. The firing part uses most of the thermal energy at $2556 \mathrm{kj} / \mathrm{kg}$. [1]. It was found that the use of $0.5-2 \%$ boric acid added samples as a fast single firing wall tile is suitable [2]. With increasing amount of boric acid, firing shrinkage 
increases. Quartz, mullite and spherical anorthite crystals were found in the microstructure [2]. The addition of $0.4-0.5 \%$ ulexite was found to shorten the grinding time, increase dry strength and reduce the firing temperature [3]. In the porcelain tiles with boric acid addition, the amount of $\mathrm{B}_{2} \mathrm{O}_{3}$ increased to $0.5-1 \%$, the firing temperature of $15{ }^{0} \mathrm{C}$ and $28{ }^{0} \mathrm{C}$ was observed respectively [4]. It was observed that the desired results were obtained in the conditions where the addition of lithium oxide to the porcelain body did not exceed 1.5\% [5]. The presence of spodumene increases mullitization reaction and gives better physical and chemical properties[6].According to Moreno et al. [4],Yet \& Kara [7] and Cigdemir et al. [8] rheological problems caused by boric acid addition in slip can be solved by electrolyte addition. It was determined that the addition of boric acid up to $0.9 \%$ did not alter of rheological properties of slip[4]. The presence of spodumene increases mullitization reaction and gives better physical and chemical properties[9].

The aim of this study is to reveal how to effect the usage of both boric acid and lithium carbonate, both of which are active flux, on sintering behaviour and microstructure of wall tile body.

\section{EXPERIMENTAL PROCEDURE}

The raw materials used in the study were obtained from Etili Seramik A.Ş (Çanakkale). Standard wall tile recipe is prepared according to Table 1. Chemical analysis of the raw materials used in the recipe is shown in Table 2. Amount of $\mathrm{Li}_{2}\left(\mathrm{CO}_{3}\right)(0.1-0.3-0.6-0.9-1.2-4$ wt.\%) were added in wall tile corresponding to each constant amount of added of $\mathrm{H}_{3} \mathrm{BO}_{3}(0.1-$ 0.3-0.6-0.9-1.2-2 wt.\%). Thus, the formation temperature of liquid phase, microstructure and physical properties of products were investigated. Grinding was carried out in a 2 kilogram alumina ball in laboratory type mill with $40 \%$ water added to the mixture and $2-3 \%$ on 63 micron sieve. The slip density was adjusted to $1680-1700 \mathrm{~g} / 1$. After that, the slip dried at 110 ${ }^{0} \mathrm{C}$ in the dryers then was moistened with $5-6 \%$ by hand and shaped by laboratory type press with $270 \mathrm{~kg} / \mathrm{cm}^{2}$ pressure. Dimensions of the samples are $7.5 \times 13 \times 1 \mathrm{~cm}$. All samples were fired in $1135{ }^{\circ} \mathrm{C} 45 \mathrm{~min}$. in continuous industrial roller kiln. The prepared samples consist of 37 different recipes in total and the prescriptions are shown in Tables 3-4-5 and 6. Scanning electron measurements were measured by SEM-JEOL JSM-7100F 20 kv, Au / Pa (80-20\%). XRD measurement was performed with PAN Analytic Empeyron Series (10-70 theta, $45 \mathrm{Kv}$, $\mathrm{K}$ alpha). Fired strength test was performed on a 3-point Gabrielli brand strength measuring instrument. In the water absorption test, the samples were first held in boiling water for 2 hours and then in cold water for 3 hours; behind this process, samples are wiped with wet towel [9]. Colour measurement values were measured with Minolta CR 300.

Table 1. Standard wall tile formulation

\begin{tabular}{|l|l|}
\hline Raw material & (wt.\%) \\
\hline Calcite & 10 \\
\hline Kaolin & 25 \\
\hline Feldspar & 25 \\
\hline Quartz & 40 \\
\hline
\end{tabular}

Table 2. Chemical analysis of raw materials (wt.\%)

\begin{tabular}{|l|l|l|l|l|l|l|l|l|l|}
\hline Raw material & $\mathrm{SiO}_{2}$ & $\mathrm{Al}_{2} \mathrm{O}_{3}$ & $\mathrm{Fe}_{2} \mathrm{O}_{3}$ & $\mathrm{CaO}$ & $\mathrm{MgO}$ & $\mathrm{Na}_{2} \mathrm{O}$ & $\mathrm{K}_{2} \mathrm{O}$ & $\mathrm{TiO}_{2}$ & L.I \\
\hline Kaolin & 77.36 & 14.76 & 0.83 & 0.54 & 0.27 & 3.49 & 6.06 & 0.28 & 1.26 \\
\hline Quartz & 99.13 & 0.35 & 0.025 & 0.02 & 0.02 & 0.27 & 0.01 & - & 0.17 \\
\hline Calcite & 0.83 & 0.31 & 0.11 & 54.9 & 0.69 & 0.07 & 0.01 & 0.01 & 43.02 \\
\hline Feldspar & 69.53 & 18.25 & 0.10 & 0.70 & 0.15 & 10.10 & 0.28 & 0.29 & 0.35 \\
\hline
\end{tabular}

L.I: Loss of ignition 
Table 3. Prepared wall tiles formulations (wt.\%)

\begin{tabular}{|l|l|l|l|l|l|l|l|l|l|}
\hline & $\mathbf{1}(\mathbf{s t d})$ & $\mathbf{2}$ & $\mathbf{3}$ & $\mathbf{4}$ & $\mathbf{5}$ & $\mathbf{6}$ & $\mathbf{7}$ & $\mathbf{8}$ & $\mathbf{9}$ \\
\hline Calcite & 10 & 10 & 10 & 10 & 10 & 10 & 10 & 10 & 10 \\
\hline Kaolin & 25 & 25 & 25 & 25 & 25 & 25 & 25 & 25 & 25 \\
\hline Feldspar & 25 & 25 & 25 & 25 & 25 & 25 & 25 & 25 & 25 \\
\hline Quartz & 40 & 40 & 40 & 40 & 40 & 40 & 40 & 40 & 40 \\
\hline $\mathrm{H}_{3} \mathrm{BO}_{3}$ & 0 & 0.1 & 0.1 & 0.1 & 0.1 & 0.1 & 0.1 & 0.3 & 0.3 \\
\hline $\mathrm{Li}_{2}\left(\mathrm{CO}_{3}\right)$ & 0 & 0.1 & 0.3 & 0.6 & 1.2 & 2 & 4 & 0.1 & 0.3 \\
\hline
\end{tabular}

Std:Standard

Table 4. Prepared wall tiles formulations (wt.\%)

\begin{tabular}{|l|l|l|l|l|l|l|l|l|l|}
\hline & $\mathbf{1 0}$ & $\mathbf{1 1}$ & $\mathbf{1 2}$ & $\mathbf{1 3}$ & $\mathbf{1 4}$ & $\mathbf{1 5}$ & $\mathbf{1 6}$ & $\mathbf{1 7}$ & $\mathbf{1 8}$ \\
\hline Calcite & 10 & 10 & 10 & 10 & 10 & 10 & 10 & 10 & 10 \\
\hline Kaolen & 25 & 25 & 25 & 25 & 25 & 25 & 25 & 25 & 25 \\
\hline Feldspat & 25 & 25 & 25 & 25 & 25 & 25 & 25 & 25 & 25 \\
\hline Quartz & 40 & 40 & 40 & 40 & 40 & 40 & 40 & 40 & 40 \\
\hline $\mathrm{H}_{3} \mathrm{BO}_{3}$ & 0.3 & 0.3 & 0.3 & 0.3 & 0.6 & 0.6 & 0.6 & 0.6 & 0.6 \\
\hline $\mathrm{Li}_{2}\left(\mathrm{CO}_{3}\right)$ & 0.6 & 1.2 & 2 & 4 & 0.1 & 0.3 & 0.6 & 1.2 & 2 \\
\hline
\end{tabular}

Table 5. Prepared wall tiles formulations (wt.\%)

\begin{tabular}{|l|l|l|l|l|l|l|l|l|l|}
\hline & $\mathbf{1 9}$ & $\mathbf{2 0}$ & $\mathbf{2 1}$ & $\mathbf{2 2}$ & $\mathbf{2 3}$ & $\mathbf{2 4}$ & $\mathbf{2 5}$ & $\mathbf{2 6}$ & $\mathbf{2 7}$ \\
\hline Calcite & 10 & 10 & 10 & 10 & 10 & 10 & 10 & 10 & 10 \\
\hline Kaolin & 25 & 25 & 25 & 25 & 25 & 25 & 25 & 25 & 25 \\
\hline Feldspar & 25 & 25 & 25 & 25 & 25 & 25 & 25 & 25 & 25 \\
\hline Quartz & 40 & 40 & 40 & 40 & 40 & 40 & 40 & 40 & 40 \\
\hline $\mathrm{H}_{3} \mathrm{BO}_{3}$ & 0.6 & 0.9 & 0.9 & 0.9 & 0.9 & 0.9 & 0.9 & 1.2 & 1.2 \\
\hline $\mathrm{Li}_{2}\left(\mathrm{CO}_{3}\right)$ & 4 & 0.1 & 0.3 & 0.6 & 1.2 & 2 & 4 & 0.1 & 0.3 \\
\hline
\end{tabular}

Table 6. Prepared wall tiles formulations (wt.\%)

\begin{tabular}{|l|l|l|l|l|l|l|l|l|l|l|}
\hline & $\mathbf{2 8}$ & $\mathbf{2 9}$ & $\mathbf{3 0}$ & $\mathbf{3 1}$ & $\mathbf{3 2}$ & $\mathbf{3 3}$ & $\mathbf{3 4}$ & $\mathbf{3 5}$ & $\mathbf{3 6}$ & $\mathbf{3 7}$ \\
\hline Calcite & 10 & 10 & 10 & 10 & 10 & 10 & 10 & 10 & 10 & 10 \\
\hline Kaolin & 25 & 25 & 25 & 25 & 25 & 25 & 25 & 25 & 25 & 25 \\
\hline Feldspar & 25 & 25 & 25 & 25 & 25 & 25 & 25 & 25 & 25 & 25 \\
\hline Quartz & 40 & 40 & 40 & 40 & 40 & 40 & 40 & 40 & 40 & 40 \\
\hline $\mathrm{H}_{3} \mathrm{BO}_{3}$ & 1.2 & 1.2 & 1.2 & 1.2 & 2 & 2 & 2 & 2 & 2 & 2 \\
\hline $\mathrm{Li}_{2}\left(\mathrm{CO}_{3}\right)$ & 0.6 & 1.2 & 2 & 4 & 0.1 & 0.3 & 0.6 & 1.2 & 2 & 4 \\
\hline
\end{tabular}

\section{RESULTS AND DISCUSSION}

\subsection{Optical Properties}

The physical appearances of the fired samples are as shown in Figure 1. The colour of the fired product changes with adding together of $\mathrm{H}_{3} \mathrm{BO}_{3}-\mathrm{Li}_{2}\left(\mathrm{CO}_{3}\right)$ that effectively effect on sintering. The chromatic coordinate measurement values of the prepared recipes are given in Table 7. In groups containing 0.1-0.3-0.6-0.9 wt. $\% \mathrm{H}_{3} \mathrm{BO}_{3}$, the $\mathrm{L}$ value decreases to $1.2 \mathrm{wt} \%$ and body's colour is obtained dark. In these $\mathrm{H}_{3} \mathrm{BO}_{3}$ groups the $\mathrm{L}$ value is increased in the addition of 2 and $4 \mathrm{wt} . \%$ of $\mathrm{Li}_{2}\left(\mathrm{CO}_{3}\right)$. The $\mathrm{L}$ value decreases until the addition of $0.6 \mathrm{wt} . \%$ of 
$\mathrm{Li}_{2}\left(\mathrm{CO}_{3}\right)$ in the group containing 1.2 and $2 \mathrm{wt} . \%$ of $\mathrm{H}_{3} \mathrm{BO}_{3}$. In the presence of 0.1-0.3-0.6-0.9 wt. $\% \mathrm{H}_{3} \mathrm{BO}_{3}$ the same type reaction take places in the presence of up to $1.2 \mathrm{wt} . \% \mathrm{Li}_{2}\left(\mathrm{CO}_{3}\right)$ and then changes the reaction in the incremental additions. This also shows that $\mathrm{H}_{3} \mathrm{BO}_{3}$ and $\mathrm{Li}_{2}$ $\left(\mathrm{CO}_{3}\right)$ affect the melting characteristics of each other's presence. According to Vilches's study on the subject can be explained by the increased vitrification and thus seen clearly effects of chromophore oxides [10]. $2 \% \mathrm{H}_{3} \mathrm{BO}_{3}+4 \% \mathrm{Li}_{2}\left(\mathrm{CO}_{3}\right)$ doped as 37 sample is formed by the high amount of low viscosity liquid phase deformation is observed.

Figure 1. Physical appearance of prepared wall tiles
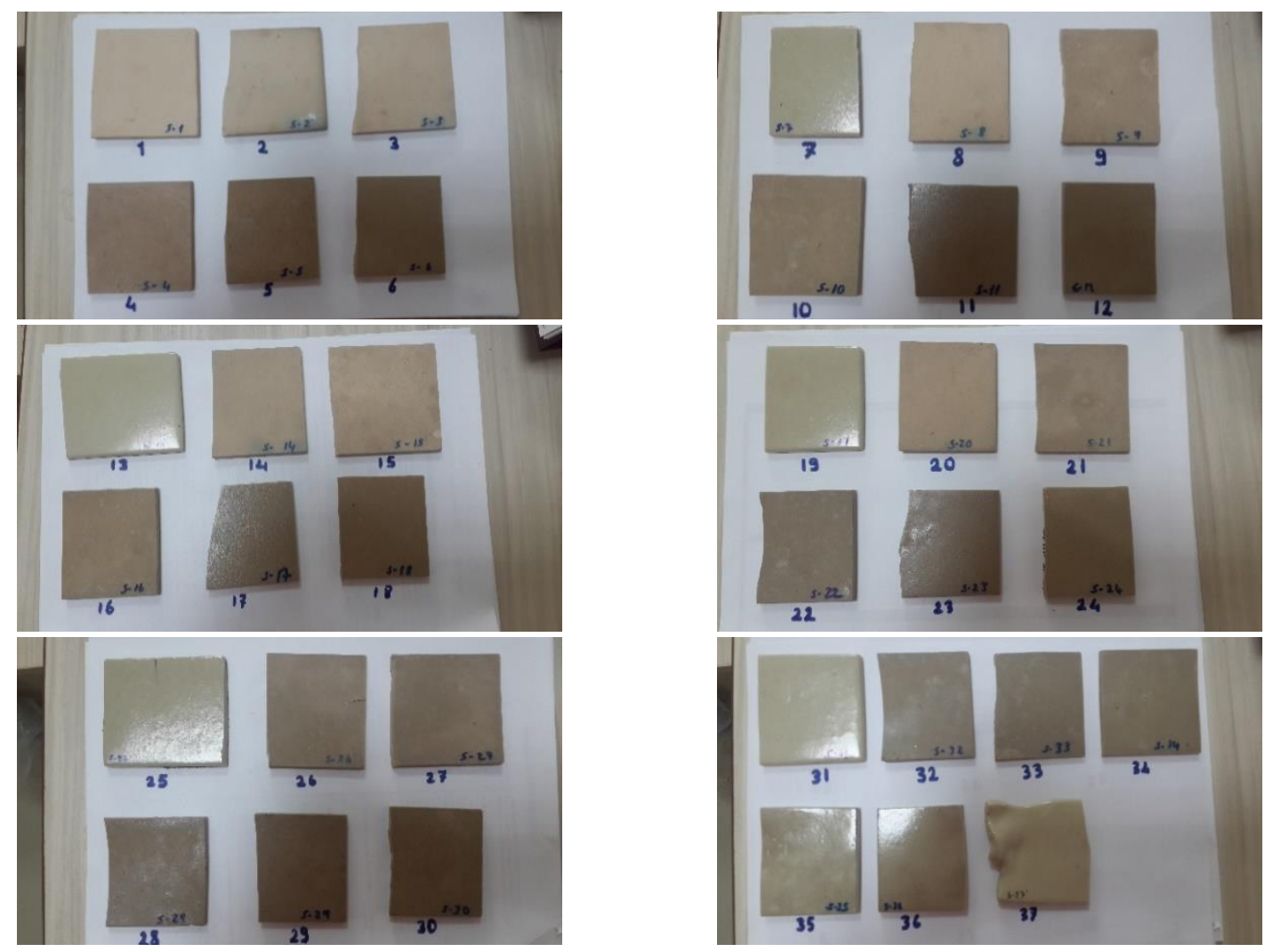

Table 7. Colorimetrer degree of prepared wall tiles

\begin{tabular}{|l|l|l|l|l|l|l|l|l|l|l|l|}
\hline no & \multicolumn{1}{|c|}{ L } & \multicolumn{1}{c|}{ a } & \multicolumn{1}{c|}{ b } & \multicolumn{1}{c|}{ no } & \multicolumn{1}{c|}{ L } & \multicolumn{1}{c|}{ a } & \multicolumn{1}{c|}{ b } & \multicolumn{1}{c|}{ no } & \multicolumn{1}{c|}{ L } & a & B \\
\hline $\mathbf{1}$ & 79.67 & 4.73 & 15.56 & $\mathbf{1 4}$ & 66.38 & 5.11 & 16.17 & $\mathbf{2 7}$ & 58.91 & 3.62 & 13.3 \\
\hline $\mathbf{2}$ & 75.15 & 3.64 & 14.02 & $\mathbf{1 5}$ & 71.2 & 4.78 & 17.23 & $\mathbf{2 8}$ & 53.65 & 3.9 & 13.24 \\
\hline $\mathbf{3}$ & 76.1 & 5.1 & 14.2 & $\mathbf{1 6}$ & 62 & 4.5 & 16.4 & $\mathbf{2 9}$ & 55.7 & 3.7 & 14.8 \\
\hline $\mathbf{4}$ & 61.95 & 6.21 & 14.26 & $\mathbf{1 7}$ & 59.11 & 3.11 & 14.26 & $\mathbf{3 0}$ & 56.29 & 3.76 & 14.92 \\
\hline $\mathbf{5}$ & 60.3 & 3.3 & 15.3 & $\mathbf{1 8}$ & 59.3 & 3.11 & 14.26 & $\mathbf{3 1}$ & 69.8 & 0.9 & 14.2 \\
\hline $\mathbf{6}$ & 60.64 & 3.32 & 15.41 & $\mathbf{1 9}$ & 70.49 & 0.93 & 14.98 & $\mathbf{3 2}$ & 56.91 & 3.1 & 12.69 \\
\hline $\mathbf{7}$ & 74.25 & 0.56 & 13.61 & $\mathbf{2 0}$ & 71.66 & 4.26 & 14.51 & $\mathbf{3 3}$ & 56.53 & 2.7 & 12.32 \\
\hline $\mathbf{8}$ & 74.89 & 5.09 & 15.87 & $\mathbf{2 1}$ & 64.01 & 4.17 & 15.21 & $\mathbf{3 4}$ & 57.9 & 2.49 & 13.14 \\
\hline $\mathbf{9}$ & 63.49 & 4.48 & 15.46 & $\mathbf{2 2}$ & 58.27 & 4.12 & 13.74 & $\mathbf{3 5}$ & 65.08 & 1.12 & 13.2 \\
\hline $\mathbf{1 0}$ & 61.67 & 4.52 & 16.46 & $\mathbf{2 3}$ & 55.38 & 3.9 & 14.12 & $\mathbf{3 6}$ & 64.23 & 2.17 & 13.99 \\
\hline $\mathbf{1 1}$ & 54.68 & 3.69 & 14.45 & $\mathbf{2 4}$ & 61.52 & 2.62 & 15.16 & $\mathbf{3 7}$ & 74.14 & 0.09 & 14.02 \\
\hline $\mathbf{1 2}$ & 58.93 & 2.95 & 14.39 & $\mathbf{2 5}$ & 69.33 & 0.67 & 13.81 & & & & \\
\hline $\mathbf{1 3}$ & 73.78 & 0.13 & 13.72 & $\mathbf{2 6}$ & 61.13 & 3.3 & 12.6 & & & & \\
\hline
\end{tabular}




\subsection{Physical Properties}

With the addition of lithium carbonate up to $2 \%$, strength increases are observed in the samples with 0.1-0.3-0.6 and $1.2 \% \mathrm{H}_{3} \mathrm{BO}_{3}$ followed by a reduced strength value. The water absorption value decreases in all trials with increasing $\mathrm{Li}_{2}\left(\mathrm{CO}_{3}\right)$. This shows that sintering increases and porosity decreases. No 8 as 0.3 wt. $\% \mathrm{H}_{3} \mathrm{BO}_{3}+0.1$ wt. $\% \mathrm{Li}_{2}\left(\mathrm{CO}_{3}\right)$ doped trial shows very close water absorption and firing shrinkage with standard wall tiles. The water absorption in the wall tile was $23.62 \%$ and the firing shrinkage was $0.69 \%$ while in $0.3 \% \mathrm{H}_{3} \mathrm{BO}_{3}$ $+0.1 \% \mathrm{Li}_{2}\left(\mathrm{CO}_{3}\right)$ added sample as number 8 , these values were respectively $19.49 \%$ and $1 \%$. In contrast the fired strength of the standard wall tile was $184.94 \mathrm{kgf} / \mathrm{cm}^{2}$ and the strength value of this recipe was increased to $334.97 \mathrm{kgf} / \mathrm{cm}^{2}$. Except for $2 \% \mathrm{H}_{3} \mathrm{BO}_{3}$ doped prescription all other $\mathrm{H}_{3} \mathrm{BO}_{3}$ additive recipes show a reduction in the firing shrinkage value of $\mathrm{Li}_{2}\left(\mathrm{CO}_{3}\right)$ up to $1.2 \%$. The water absorption value reaches zero by $1.2 \% \mathrm{Li}_{2}\left(\mathrm{CO}_{3}\right)$ in all boric acid samples except $0.1 \% \mathrm{H}_{3} \mathrm{BO}_{3}$. In the group containing $0.1 \% \mathrm{H}_{3} \mathrm{BO}_{3}$. the water absorption value reaches to zero with the addition of $2 \% \mathrm{Li}_{2}\left(\mathrm{CO}_{3}\right)$. In a study by Cengiz and Kara [2], water absorption and firing shrinkage in the addition of $2 \% \mathrm{H}_{3} \mathrm{BO}_{3}$ to the wall tile were found to be $17.2 \%$ and $1.4 \%$ respectively. Added $0.1 \% \mathrm{Li}_{2}\left(\mathrm{CO}_{3}\right)+2 \% \mathrm{H}_{3} \mathrm{BO}_{3}$ body's water absorption and fired shrinkage's values were found as $6.5 \%$ and $8.38 \%$ respectively. The decrease in the water absorption value and the increase in the fired shrinkage indicate that an active sintering mechanism has taken place.

Figure 2 a According to quantity of $\mathrm{Li}_{2}\left(\mathrm{CO}_{3}\right)$ in 0.1 wt. \% added $\mathrm{H}_{3} \mathrm{BO}_{3}$ sample's fired flexural strength-water absorption graphic.

b According to quantity of $\mathrm{Li}_{2}\left(\mathrm{CO}_{3}\right)$ in $0.3 \mathrm{wt} \%$ added $\mathrm{H}_{3} \mathrm{BO}_{3}$ sample's fired strength-water absorption graphic

(a)

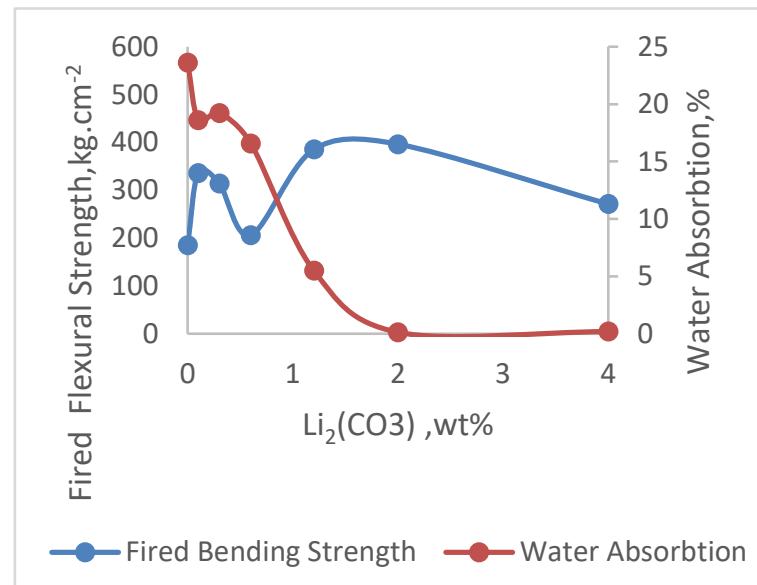

(b)

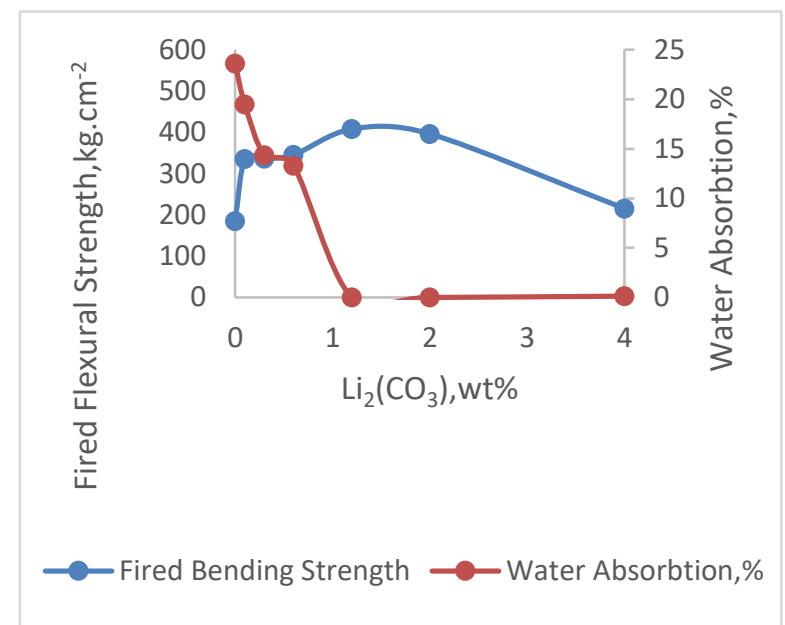

(All figure's first degrees are standard samples without $\mathrm{H}_{3} \mathrm{BO}_{3}$ and $\mathrm{Li}_{2}\left(\mathrm{CO}_{3}\right)$ 
Figure 3 a According to quantity of $\mathrm{Li}_{2}\left(\mathrm{CO}_{3}\right)$ in 0.6 wt. \% added $\mathrm{H}_{3} \mathrm{BO}_{3}$ sample's fired flexural strength-water absorption graphic

b According to quantity of $\mathrm{Li}_{2}\left(\mathrm{CO}_{3}\right)$ in 0.9 wt.\% added $\mathrm{H}_{3} \mathrm{BO}_{3}$ sample's fired flexural strength-water absorption graphic

(a)

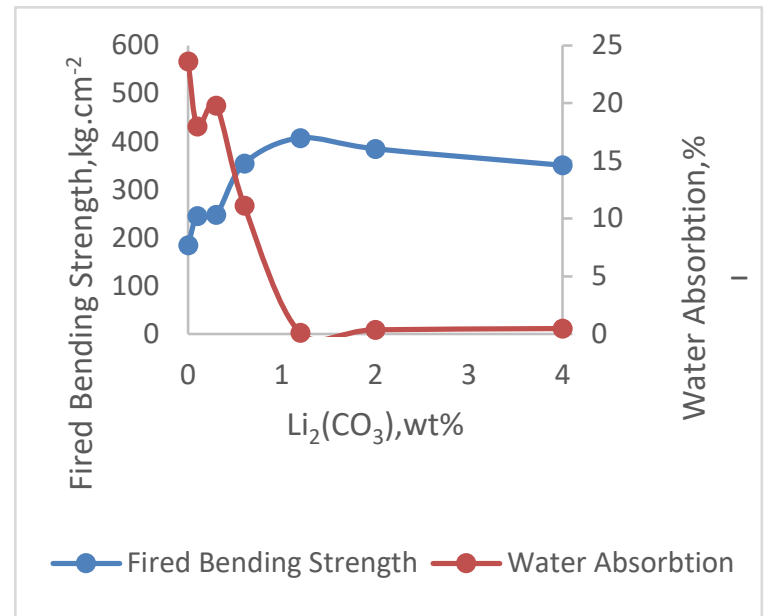

(b)

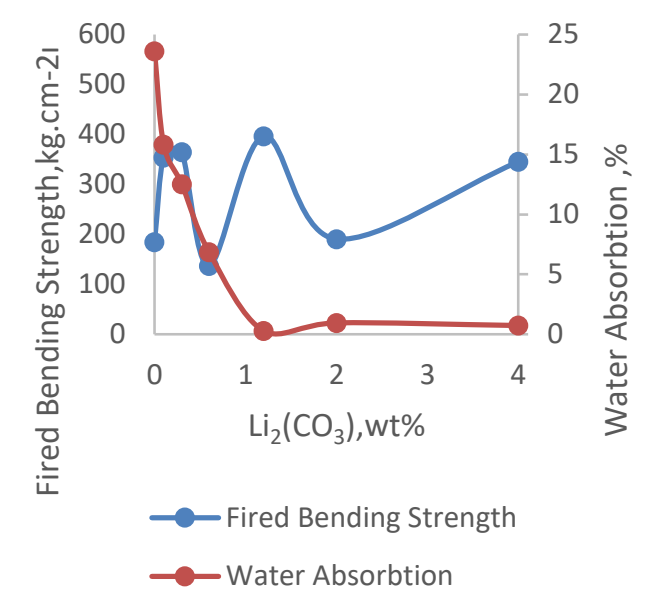

(All figure's first degrees are standard samples without $\mathrm{H}_{3} \mathrm{BO}_{3}$ and $\mathrm{Li}_{2}\left(\mathrm{CO}_{3}\right)$

Figure 4 a According to quantity of $\mathrm{Li}_{2}\left(\mathrm{CO}_{3}\right)$ in $1.2 \mathrm{wt} . \%$ added $\mathrm{H}_{3} \mathrm{BO}_{3}$ sample's fired flexural strength-water absorption graphic

b According to quantity of $\mathrm{Li}_{2}\left(\mathrm{CO}_{3}\right)$ in 2 wt. \% added $\mathrm{H}_{3} \mathrm{BO}_{3}$ sample's fired flexural strength-water absorption graphic

(a)

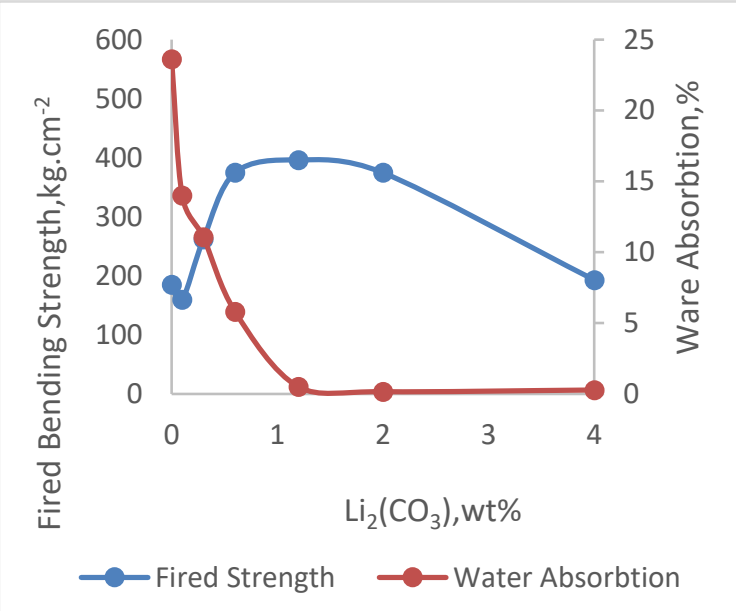

(b)

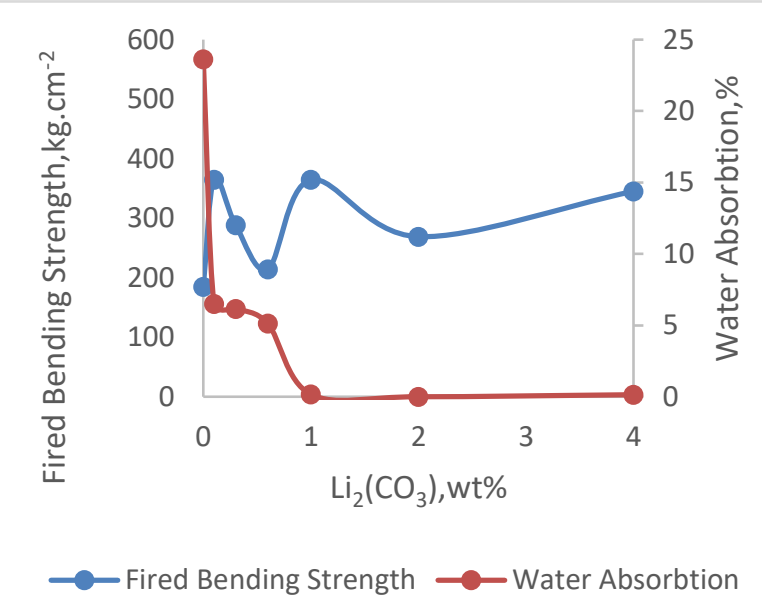

(All figure's first degrees are standard samples without $\mathrm{H}_{3} \mathrm{BO}_{3}$ and $\mathrm{Li}_{2}\left(\mathrm{CO}_{3}\right.$ ) 
Figure 5. a.b.c.d.e.f respectively $0.1-0.3-0.6-0.9-1.2$ ve 2 wt. $\% \mathrm{H}_{3} \mathrm{BO}_{3}$ contain wall tile sample's fired shirinkage-wt. $\% \mathrm{Li}_{2}\left(\mathrm{CO}_{3}\right)$ graphics.

a)

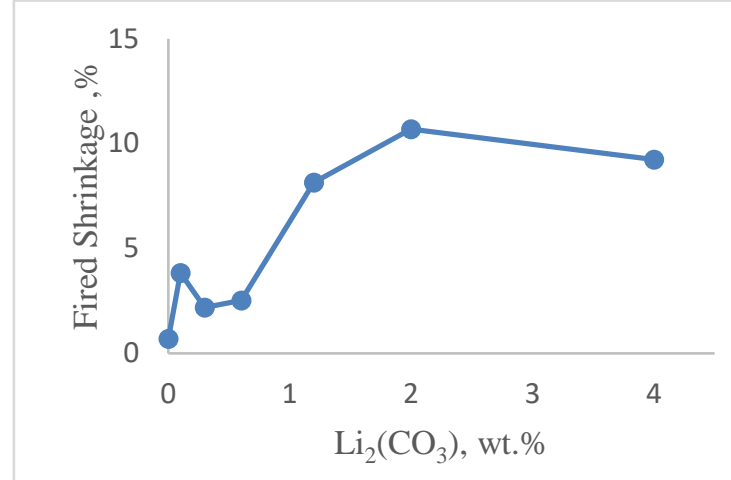

c)

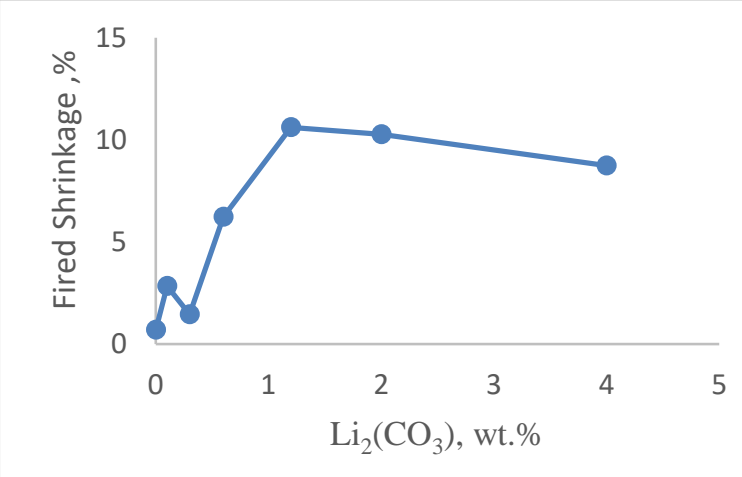

e)

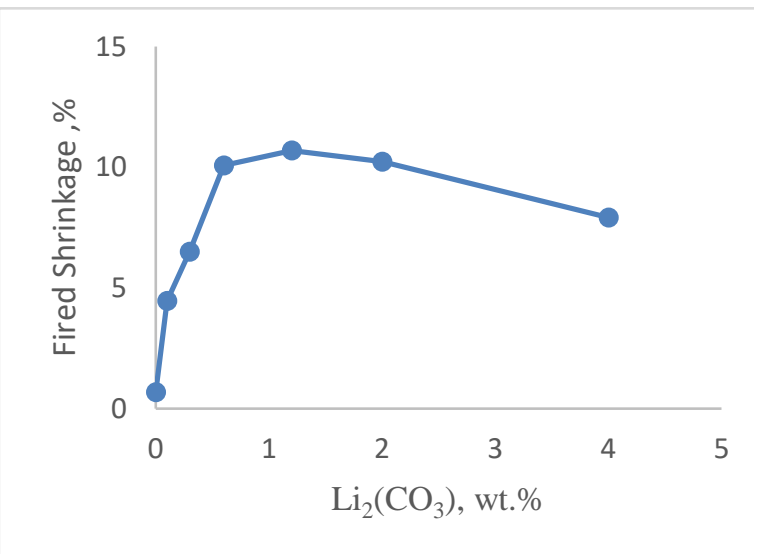

b)

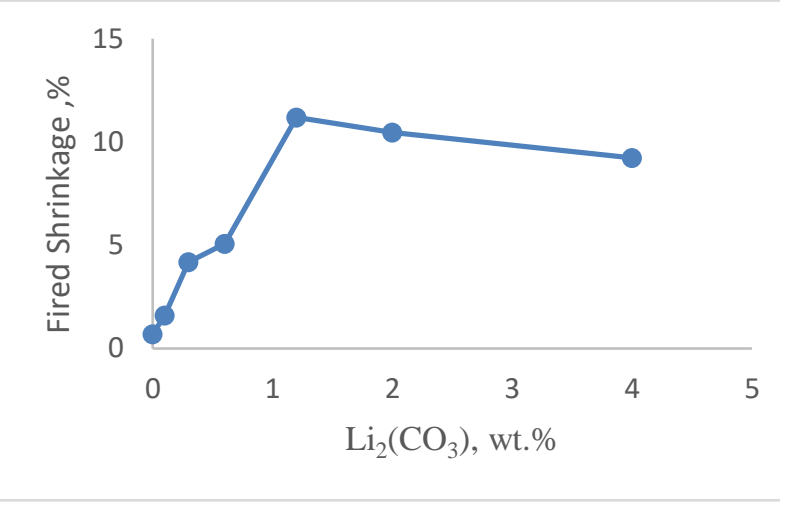

d)

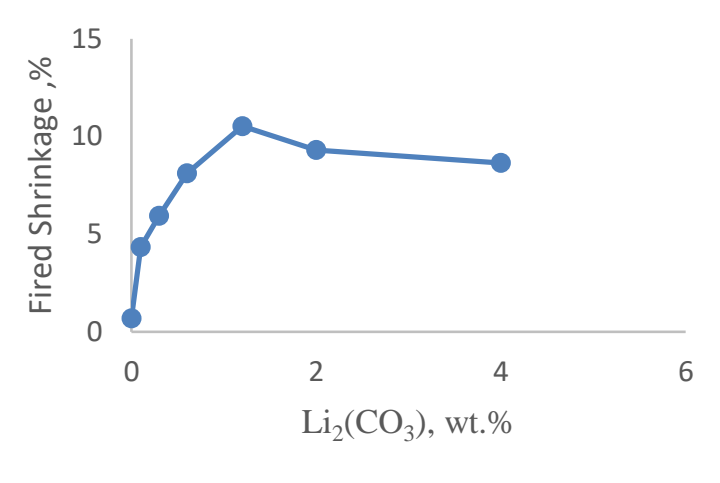

f)

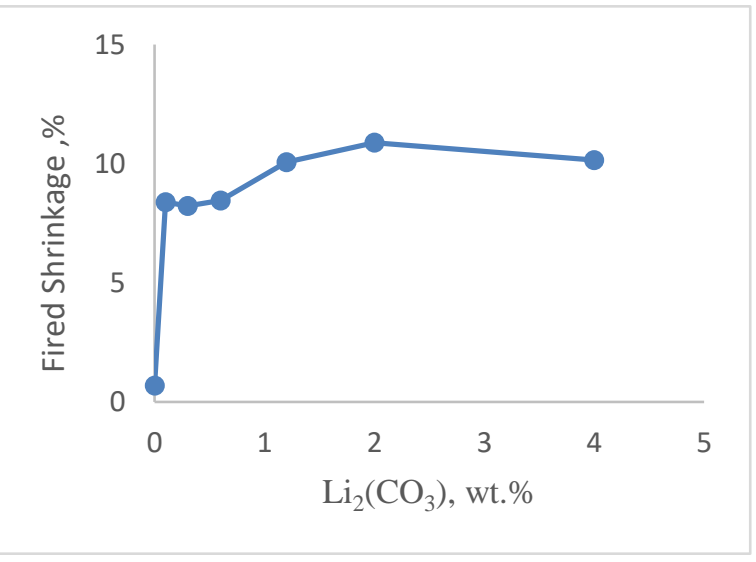

\subsection{Rheological Behaviour}

The viscosity of the standard sample measured with fordcup is 29 seconds, while the alternate body number 8 's $\left(0.3 \% \mathrm{H}_{3} \mathrm{BO}_{3}+0.1 \% \mathrm{Li}_{2}\left(\mathrm{CO}_{3}\right.\right.$ added $)$ is 36 seconds. According to Moreno [4], the addition of up to $0.9 \%$ of $\mathrm{H}_{3} \mathrm{BO}_{3}$ does not alter the rheological properties.

\subsection{Microstructral Analysis}

The secondary electron images of the standard body and $\mathrm{H}_{3} \mathrm{BO}_{3}-\mathrm{Li}_{2}\left(\mathrm{CO}_{3}\right)$ doped wall tile bodies obtained from the fractured surfaces of the bodies are shown in Figure 6. It is observed that the glassy phase is formed by the increasing amount of boric acid and lithium 
carbonate and hence the sintering takes place rapidly. Particularly number 7, 11, 32 and 37 added $0.1 \% \mathrm{H}_{3} \mathrm{BO}_{3}+4 \% \mathrm{Li}_{2}\left(\mathrm{CO}_{3}\right), 3 \% \mathrm{H}_{3} \mathrm{BO}_{3}+1.2 \% \mathrm{Li}_{2}\left(\mathrm{CO}_{3}\right), 2 \% \mathrm{H}_{3} \mathrm{BO}_{3}+0.1 \% \mathrm{Li}_{2}\left(\mathrm{CO}_{3}\right)$, $2 \% \mathrm{H}_{3} \mathrm{BO}_{3}+4 \% \mathrm{Li}_{2}\left(\mathrm{CO}_{3}\right)$ respectively have high percentage of glassy phase are seen in the experiment. The number of seven while the size of the pores with increasing value of $0.1 \%$ $\mathrm{H}_{3} \mathrm{BO}_{3}+4 \% \mathrm{Li}_{2}\left(\mathrm{CO}_{3}\right)$ increased and there was a wide por size distribution. The number of 11 pore's, which is added $0.3 \% \mathrm{H}_{3} \mathrm{BO}_{3}+1.2 \% \mathrm{Li}_{2}\left(\mathrm{CO}_{3}\right)$, were reduced and narrow por size distribution is observed. With the addition of $2 \% \mathrm{H}_{3} \mathrm{BO}_{3}+0.1 \% \mathrm{Li}_{2}\left(\mathrm{CO}_{3}\right)$ supplemented with the same boric acid amount as 37 and $2 \% \mathrm{H}_{3} \mathrm{BO}_{3}+4 \% \mathrm{Li}_{2}\left(\mathrm{CO}_{3}\right)$ addition, the pores are increased in size with increasing $\mathrm{Li}_{2}\left(\mathrm{CO}_{3}\right)$. The maximum strength of $0.3 \% \mathrm{H}_{3} \mathrm{BO}_{3}+2 \% \mathrm{Li}_{2}$ $\left(\mathrm{CO}_{3}\right)$ added 11 is believed to result in eutectic and high viscosity and low viscosity glassy phase. SEM images of the experiment with $0.1 \% \mathrm{H}_{3} \mathrm{BO}_{3}+0.1 \% \mathrm{Li}_{2}\left(\mathrm{CO}_{3}\right)$ which is an alternative wall tile prescription of 8 are similar with the standard wall tiles. $0.1 \mathrm{wt} . \% \mathrm{H}_{3} \mathrm{BO}_{3}+$ 4 wt. $\% \mathrm{Li}_{2}\left(\mathrm{CO}_{3}\right)$ addition prescription is the recipe with the minimum amount of $\mathrm{H}_{3} \mathrm{BO}_{3}$ and the sintering is provided because of the presence of $4 \% \mathrm{Li}_{2}\left(\mathrm{CO}_{3}\right)$. While this recipe shows a wide pore size distribution, the pore size distribution in the no 11 sample $0.3 \mathrm{wt} . \% \mathrm{H}_{3} \mathrm{BO}_{3}+1.2$ wt. $\% \mathrm{Li}_{2}\left(\mathrm{CO}_{3}\right)$ added sample narrowed and the small pores are generally dispersed in the glassy structure. 32 no sample, which is added $2 \mathrm{wt} . \% \mathrm{H}_{3} \mathrm{BO}_{3}+0.1 \mathrm{wt} . \% \mathrm{Li}_{2}\left(\mathrm{CO}_{3}\right)$ trial shows medium and small pores with narrow pore size distribution and no 37 sample $2 \% \mathrm{H}_{3} \mathrm{BO}_{3}+4 \% \mathrm{Li}_{2}\left(\mathrm{CO}_{3}\right)$ added trial in the experiment large and small 2 size pore. According to Iqbal \& Lee [11], the decrease in the size of the pores and the increase in the size of the glassy structure can be attributed to the easier integration of the pores by decreasing the viscosity. No 7 although the amount of boric acid with $0.1 \mathrm{wt} . \% \mathrm{H}_{3} \mathrm{BO}_{3}+4 \mathrm{wt} . \% \mathrm{Li}_{2}\left(\mathrm{CO}_{3}\right)$ is low, the presence of lithium carbonate decreases the initial temperature of the liquid phase required for sintering with boric acid. increases the amount and decreases the viscosity of the glassy structure. According to Eplerr [12], the $\mathrm{Li}_{2} \mathrm{O}-\mathrm{SiO}_{2}-\mathrm{Al}_{2} \mathrm{O}_{3}$ triple system constitutes approximately $15 \% \mathrm{Li}_{2} \mathrm{O}-79 \% \mathrm{SiO}_{2}-$ $8 \% \mathrm{Al}_{2} \mathrm{O}_{3}$ eutectic below $1000{ }^{\circ} \mathrm{C}[13]$. It is thought that boric acid is involved in eutectic formation and this effect is effective in reducing the temperature and decreasing the viscosity of the glassy phase. 
Figure 6 a 1 no sample (standart wall tiles)

b 2 no sample $\left(\mathrm{H}_{3} \mathrm{BO}_{3} 0.1 \mathrm{wt} . \%+\mathrm{Li}_{2}\left(\mathrm{CO}_{3}\right) 0.1 \mathrm{wt} . \%\right.$

c 7 no sample $\left(\mathrm{H}_{3} \mathrm{BO}_{3} 0.1 \mathrm{wt} . \%+\mathrm{Li}_{2}\left(\mathrm{CO}_{3}\right) 4\right.$ wt.\%)

d 8 no sample $\left(\mathrm{H}_{3} \mathrm{BO}_{3} 0.3 \mathrm{wt} . \%+\mathrm{Li}_{2}\left(\mathrm{CO}_{3}\right) 0.1 \mathrm{wt} . \%\right.$ (replacing wall tiles)

e 11no sample $\left(\mathrm{H}_{3} \mathrm{BO}_{3} 0.3 \mathrm{wt} . \%+\mathrm{Li}_{2}\left(\mathrm{CO}_{3}\right) 1.2 \mathrm{wt} . \%\right)$ (Max.strength)

f 32 no sample $\left(\mathrm{H}_{3} \mathrm{BO}_{3} 2 \mathrm{wt} . \%+\mathrm{Li}_{2}\left(\mathrm{CO}_{3}\right) 0.1 \mathrm{wt} . \%\right.$

g 37 no sample $\left(\mathrm{H}_{3} \mathrm{BO}_{3} 2\right.$ wt.\% + $\mathrm{Li}_{2}\left(\mathrm{CO}_{3}\right) 4$ wt.\%) sample's SEM photographs

(a) 1 no sample

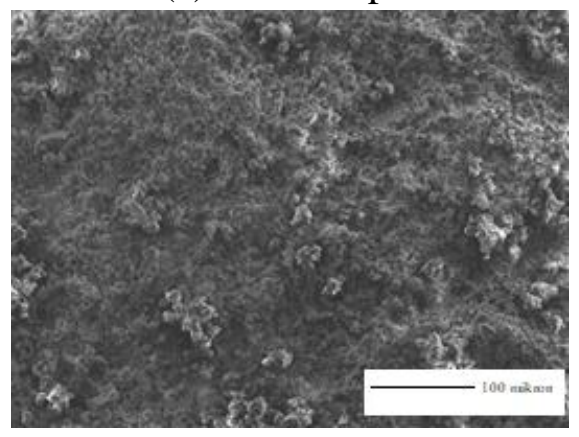

(c) 7 no sample

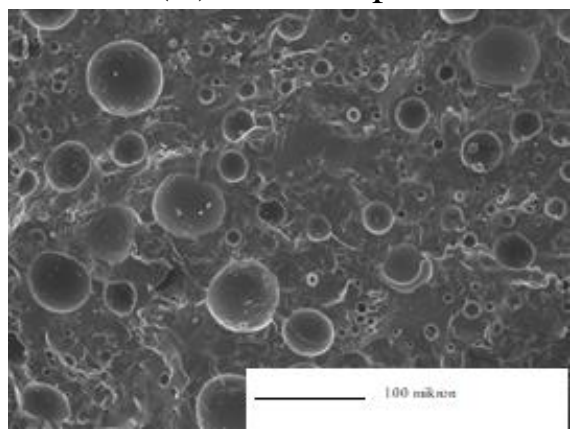

(e) 11 no sample

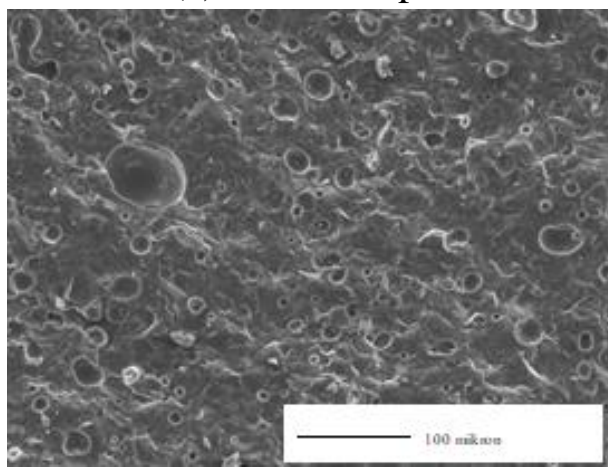

b) 2 no sample

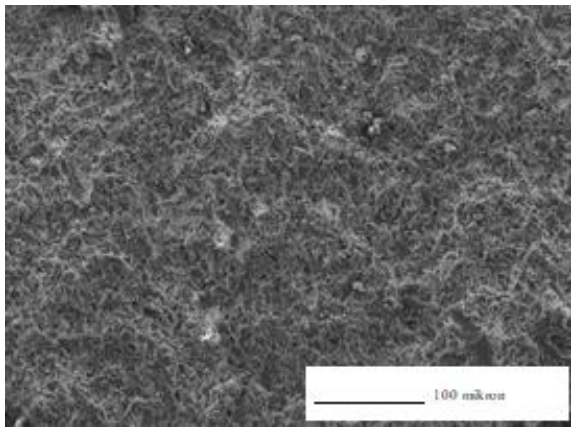

(d) 8 no sample

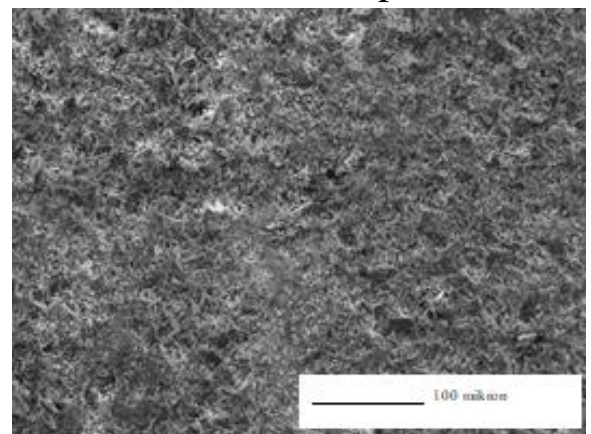

(f) 32 no sample

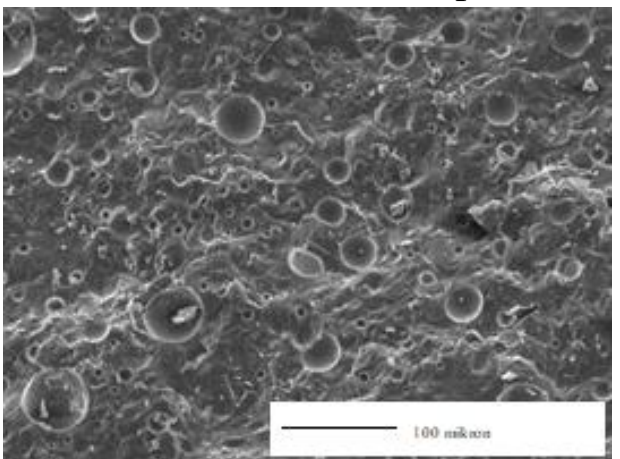

(g ) 37 no sample

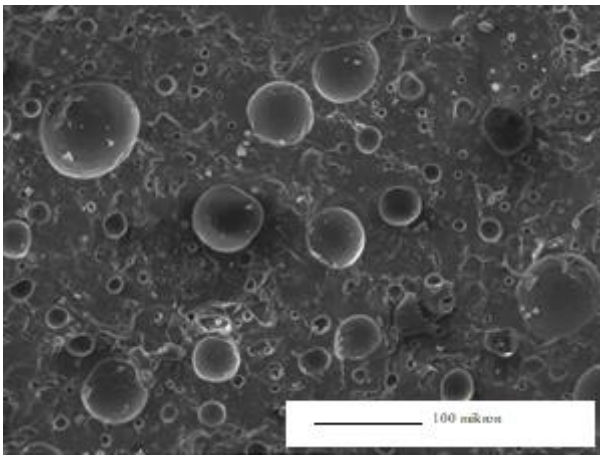




\subsection{Phase Analysis}

The crystalline phases in the samples of the wall tiles are given in Figure 7. Kurama et al. [14], as shown in the study on the subject, as a result of the system's low firing temperature and short firing time is available free quartz. In addition, plagioclases and low quantity of mullites phases were detected. In no 7 (added $\mathrm{H}_{3} \mathrm{BO}_{3} 0.1$ wt.\% $\mathrm{Li}_{2}\left(\mathrm{CO}_{3}\right) 4$ wt.\%) and no 37 (added $\mathrm{H}_{3} \mathrm{BO}_{3} 2 \mathrm{wt} . \%+\mathrm{Li}_{2}\left(\mathrm{CO}_{3}\right) 4 \mathrm{wt} . \%$ ) samples mullite formation occur due to low viscosity of glassy phase. According to Low et all. [15], the use of spodumene provides better physical and mechanical properties to ceramics. Prescription 1-2 and 8 no samples show mullite peaks. In experiment $37\left(\mathrm{H}_{3} \mathrm{BO}_{3} 2 \mathrm{wt} . \%+\mathrm{Li}_{2}\left(\mathrm{CO}_{3}\right) 4 \mathrm{wt} . \%\right)$ quartz content is low; the reason for this is that the viscosity of the liquid phase formed is low and thus its activity is high. No 2 as 0.1 wt. $\% \mathrm{H}_{3} \mathrm{BO}_{3}+\mathrm{Li}_{2}\left(\mathrm{CO}_{3}\right) 0.1$ wt. $\%$ added and no 8 as 0.3 wt. $\% \mathrm{H}_{3} \mathrm{BO}_{3}+0.1$ wt. $\% \mathrm{Li}_{2}\left(\mathrm{CO}_{3}\right)$ added, despite of the same amount of $\mathrm{Li}_{2}\left(\mathrm{CO}_{3}\right)$, the quartz dissolution in glassy phase decreased with increasing $\mathrm{H}_{3} \mathrm{BO}_{3}$ no 8 as $\mathrm{H}_{3} \mathrm{BO}_{3} 0.3$ wt. $\% \mathrm{H}_{3} \mathrm{BO}_{3}+0.1$ wt.\% $\mathrm{Li}_{2}\left(\mathrm{CO}_{3}\right)$ added recipe is close to the XRD graphics of the standard wall tile and from the strength measurements that no 8 sample has a better strength value.

Figure 7. Fired wall tiles sample's XRD patterns (Q: Quartz. M: Mullite. P: Plagioaclase. )

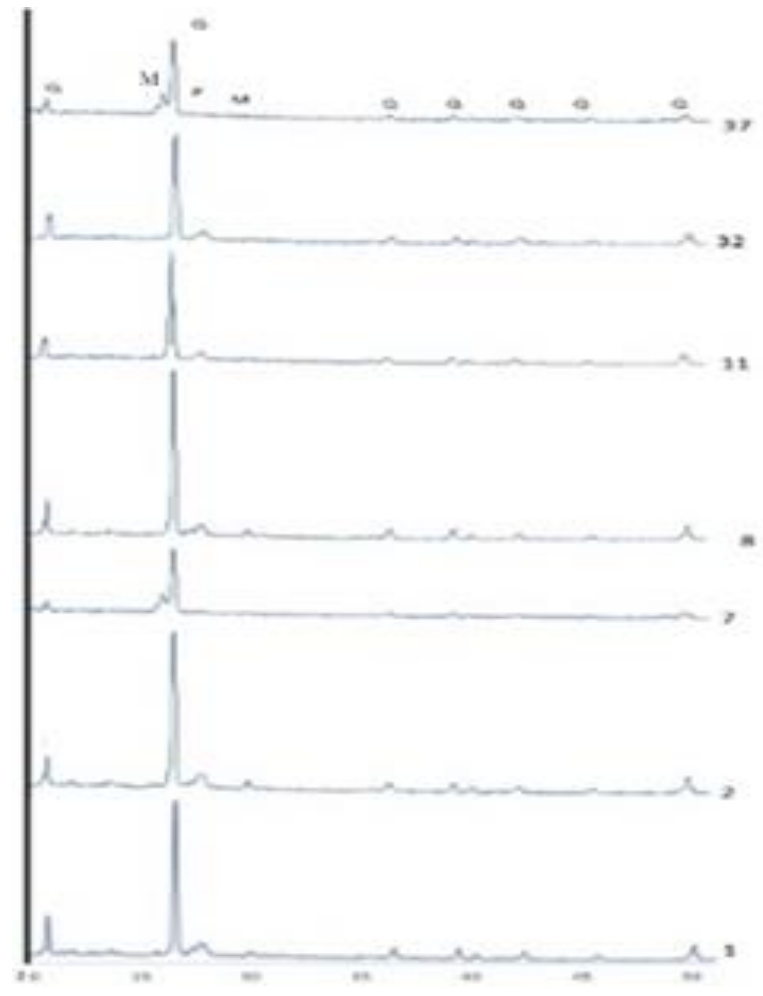

\subsection{Firing Behaviour}

In the optical dilatometer graphics of the prepared samples, it was observed that only 7 and 37 of the experiment were sintered in $1050{ }^{\circ} \mathrm{C}$ at 50 minutes firing time. In no 7 sample, which is added 0.1 wt. $\% \mathrm{H}_{3} \mathrm{BO}_{3}+4$ wt. $\% \mathrm{Li}_{2}\left(\mathrm{CO}_{3}\right)$, the fastest sintering's temperature is 1038 ${ }^{0} \mathrm{C}$. Whereas in the sample 37 , which is added 2 wt. $\% \mathrm{H}_{3} \mathrm{BO}_{3}+4$ wt. $\% \mathrm{Li}_{2}\left(\mathrm{CO}_{3}\right)$, the fastest sintering's temperature is $1032{ }^{\circ} \mathrm{C}$. In standard wall tile and other doped samples, sintering does not appear in this temperature. According to Cengiz \& Kara [7] in the standard wall tile body, the temperature, which sintering is the fastest is $1148^{\circ} \mathrm{C}$, which the other name is flex point. Whereas added $1 \% \mathrm{H}_{3} \mathrm{BO}_{3}$ body's fastest sintering's temperature is $1142{ }^{\circ} \mathrm{C}$. Figure 7 shows the optical dilatometer graphics of the selected experiments. 
Figure 8 a) 1-2-7-8-11-32-37 no sample's dilatometric curves b) 7 no sample $0.1 \mathrm{wt} . \% \mathrm{H}_{3} \mathrm{BO}_{3}+4 \mathrm{wt} . \% \mathrm{Li}_{2}\left(\mathrm{CO}_{3}\right)$ added wall tile's dilatometric curve c) 37 no sample 2 wt. $\% \mathrm{H}_{3} \mathrm{BO}_{3}+4$ wt. $\% \mathrm{Li}_{2}\left(\mathrm{CO}_{3}\right)$ added wall tile's dilatometric curve

a)

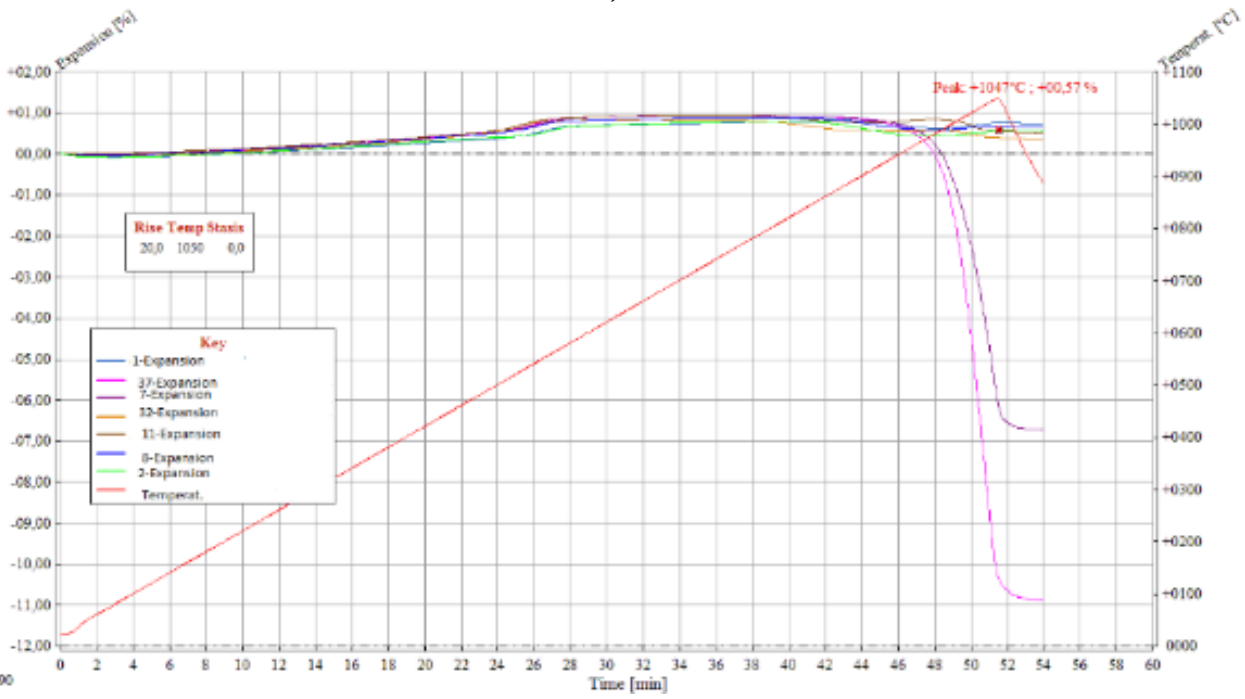

b)

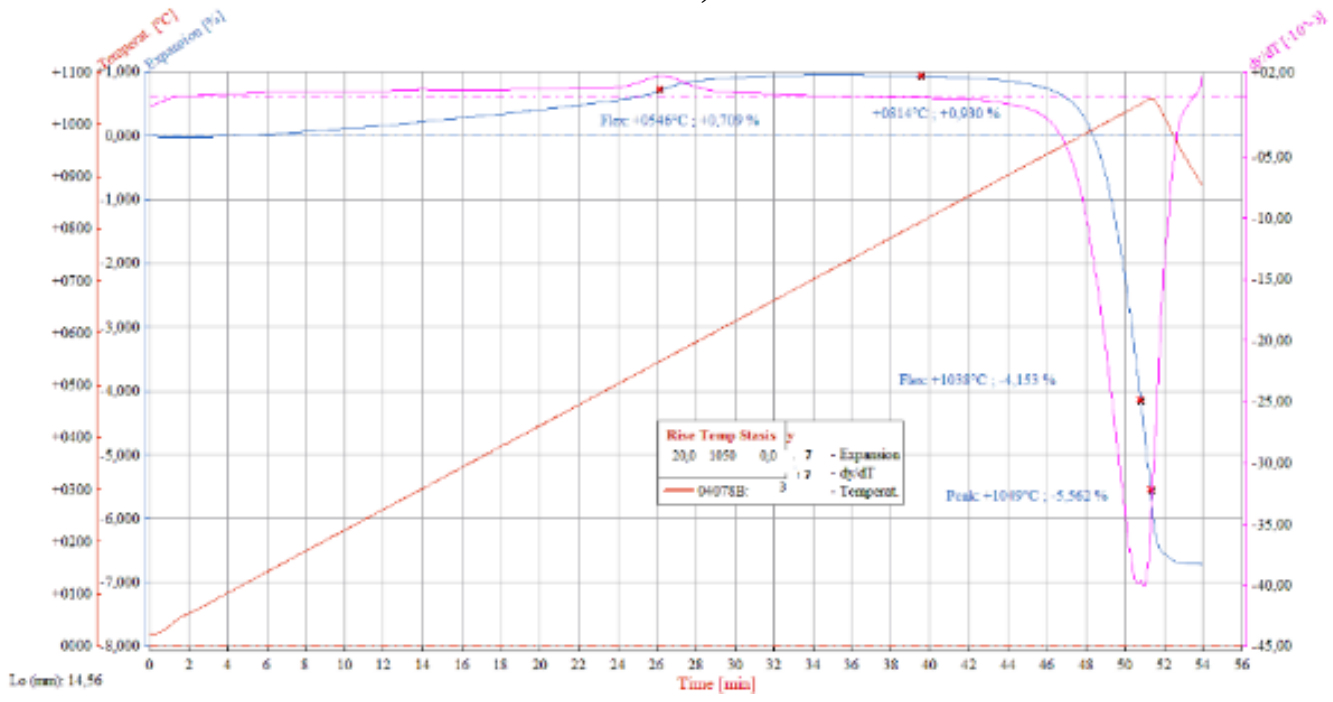

(c)

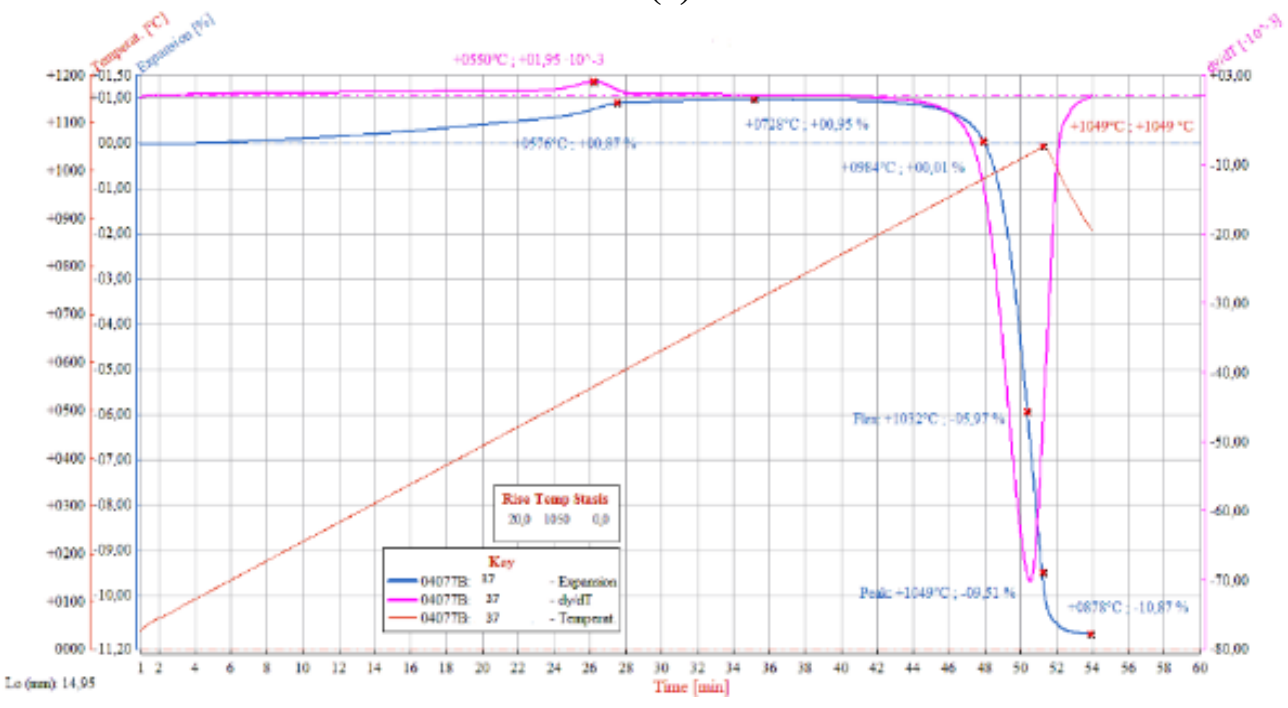


Thermogravimetric and differential thermal analysis of standard and alternative masse 8 are given in figures $9-10-11$ and 12. The characteristic endothermic peaks of the standard and the number 8 were 59.8,518.3, 577 and $773{ }^{\circ} \mathrm{C}$ and $60.8,521.9,576$ and $772.5{ }^{\circ} \mathrm{C}$, respectively. The first peak, second, third and fourth peaks show the temperature of the water absorbed physically, the temperature of formation of the metakaolin, the quartz alpha beta conversion and the decay temperature of $\mathrm{CaCO}_{3}$, respectively. An exothermic peak was observed in the standard sample at $997.6{ }^{\circ} \mathrm{C}$, whereas in the 8. prescription it was observed at $995.3{ }^{\circ} \mathrm{C}$ and more severe. It is thought that the increase in strength is caused by anorthite mineral formation [16]. Since the thermogravimetry curve of the alternative mass is below the standard mass, the formation of metakaolin and the decomposition of $\mathrm{CaCO}_{3}$ in the alternative mass show that the reaction is efective. When the DTG graph is seen, the temperature at which the formation temperature of metakaolan is most rapid is $508.8{ }^{\circ} \mathrm{C}$ and the temperature is $506{ }^{\circ} \mathrm{C}$ in standard mass. The temperature at which the calcite is decomposed most rapidly is 766.7 and $767.40 \mathrm{C}$ in the alternative receipe and the standard. The mass loss resulting from the calcite decomposition of the standard mass appears to be $4.60 \%$ while the alternative mass is $4.60 \%$. This shows that the body reacts with a small amount of the Ca element in the calcite which decomposes. The starting and ending temperature of decomposition of calcite in both bodies did not change.

Figure 9. Thermogravimetric analysis of standart receipe

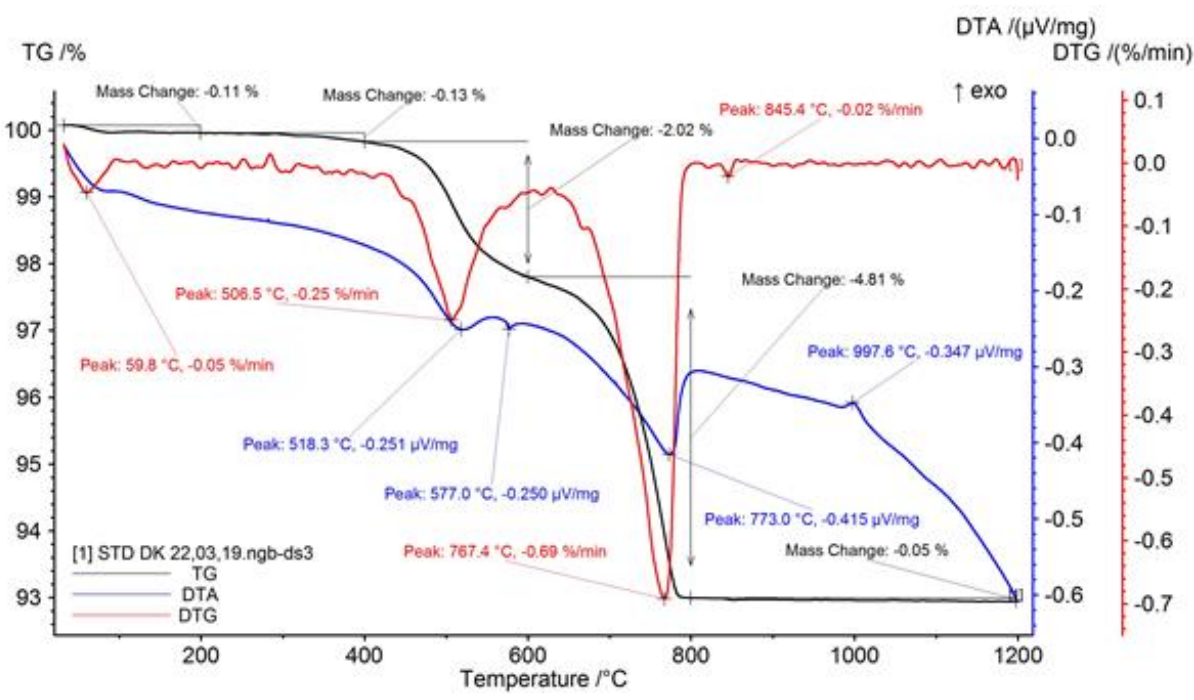

Figure10 Thermogravitmeric analysis of alternative receipe (8 no receipe)

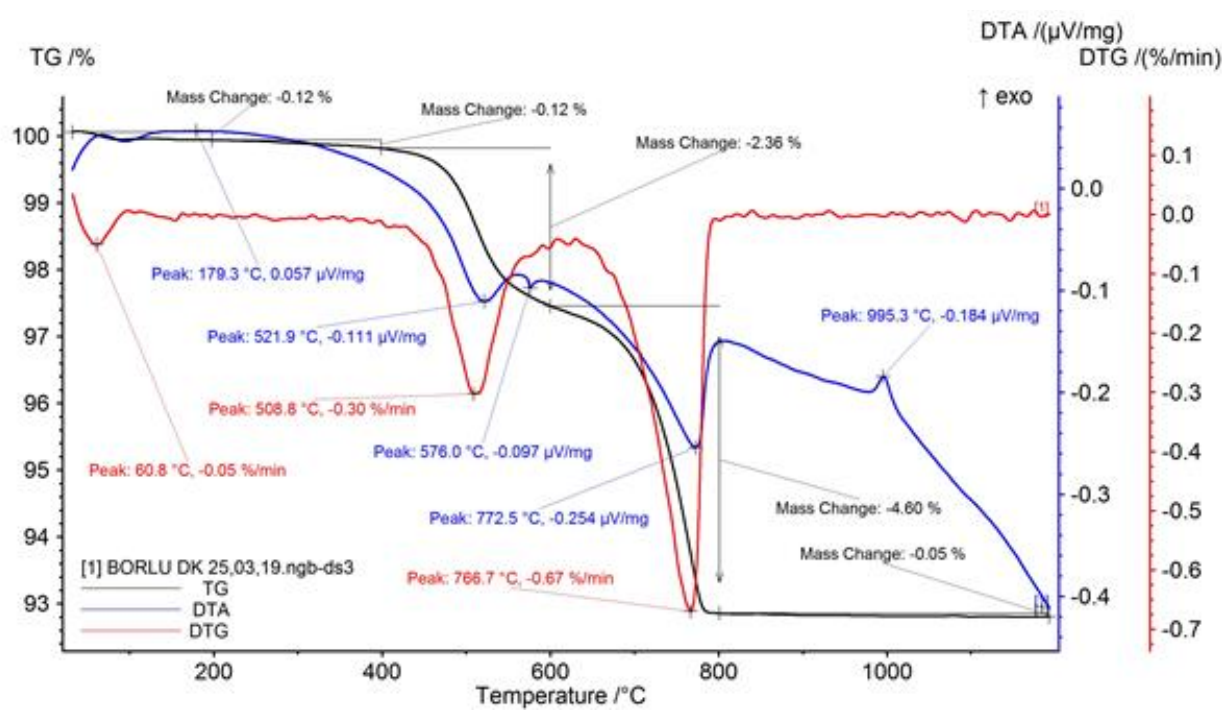


Figure 11.Thermogravimetric and differantial thermogravimetric analysis of both of the standard and alternative receipe.

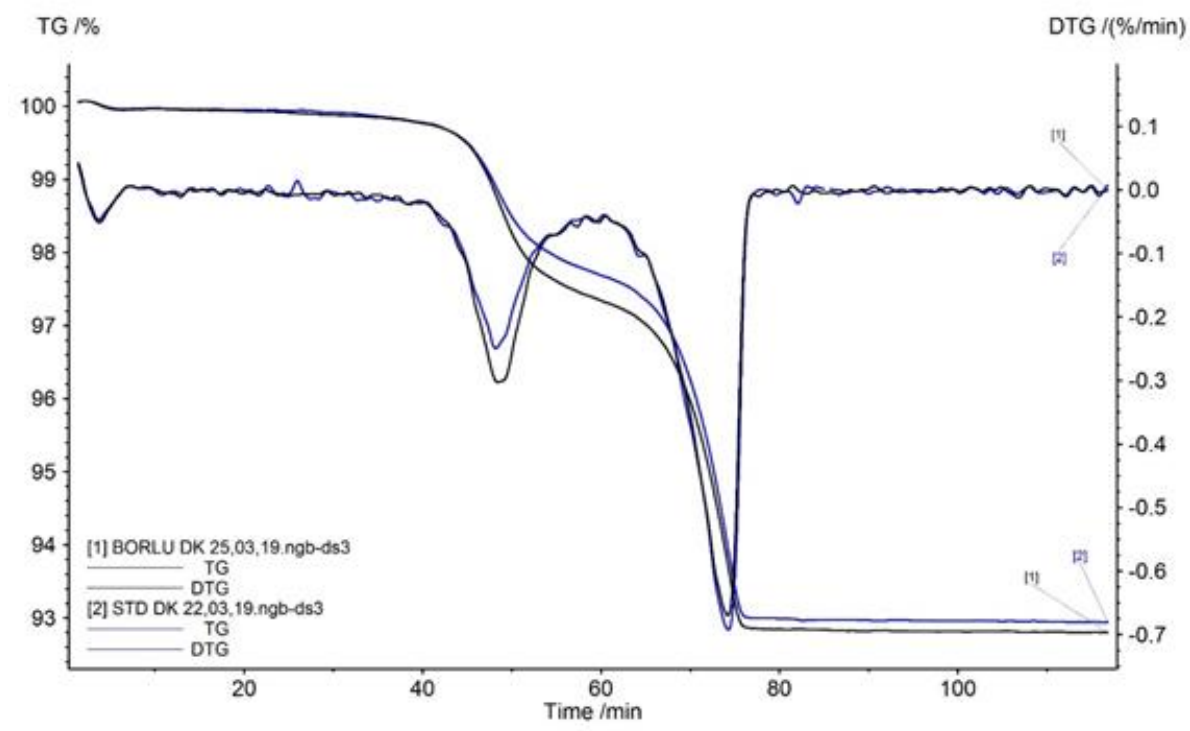

Figure 12. Differantial thermal analyses of both of standard anf alternative receipe

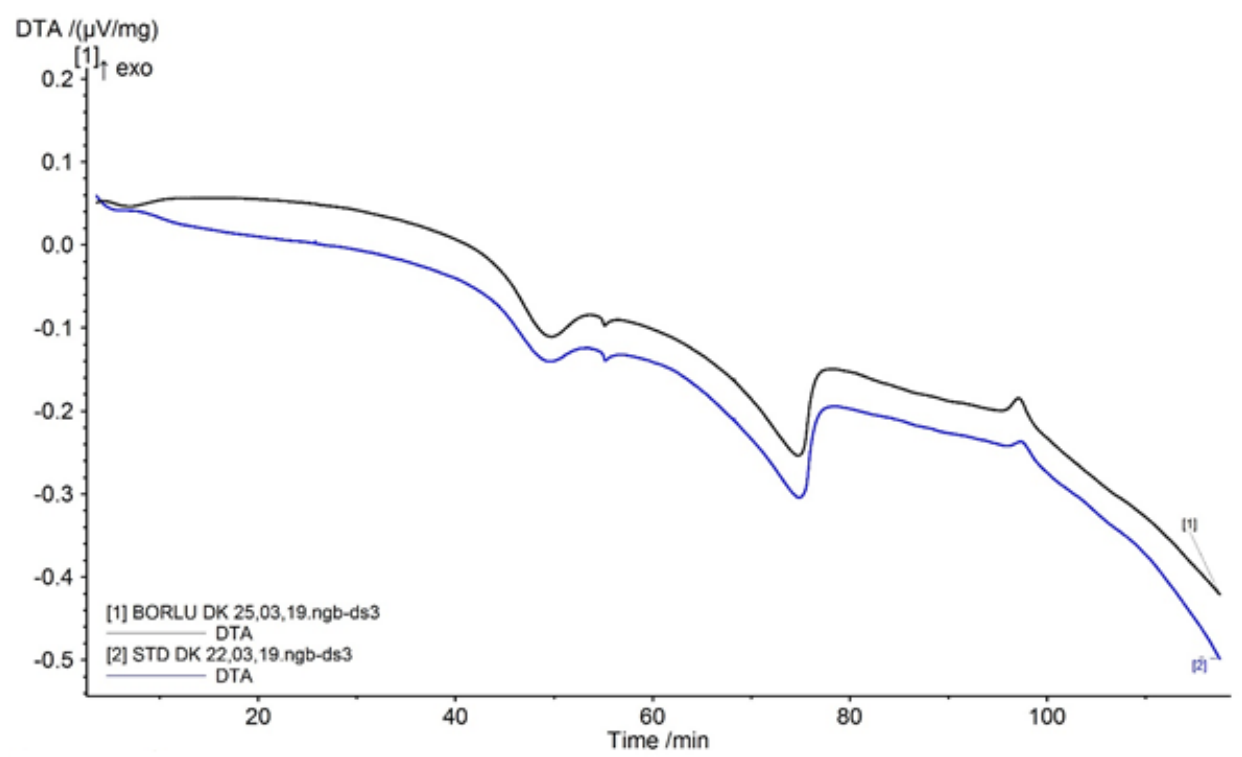

\section{CONCLUSIONS}

The combined use of $\mathrm{H}_{3} \mathrm{BO}_{3}$ and $\mathrm{Li}_{2}\left(\mathrm{CO}_{3}\right)$ allows an active liquid phase sintering than the individual adding. The combined use of the active flux increases the mullitization reactions and gives better physical and chemical characteristics. The decomposition of $\mathrm{CaCO}_{3}$ does not change with the added flux. $0.3 \mathrm{wt} . \% \mathrm{H}_{3} \mathrm{BO}_{3}+0.1 \mathrm{wt} \% \mathrm{Li}_{2}\left(\mathrm{CO}_{3}\right)$ doped wall tile test showed similar water absorption and firing value with standard wall tile. The samples contain this added ratio show the fired strength is $334.97 \mathrm{kgf} / \mathrm{cm}^{2}$ whereas the standard wall tile's strength is $184.94 \mathrm{kgf} / \mathrm{cm}^{2}$. 


\section{REFERENCES}

[1] MEZQUITA, A., BOIX, J., MONFORT, E., MALLOL G, 2014, Energy Saving In Ceramic Tile Kilns: Cooling Gas Heat Recovery, Aplied Termal Engineering. 65. 101-110.

[2] CENGİZ, Ö., KARA, A., Tek Pişim Duvar Karosu Bünyelerinde Borik Asit İlavesinin Sinterleme Davranışına Etkileri, Afyon Kocatepe Üniversitesi Fen Bilimleri Dergisi, Özel Sayı, 29-35

[3] SOMANY, S., TRIVEDI, G.G., SRIDHAR, T., GOEL, A., MOHANTY, D., PITCHUMANI, B., 2014, Increase In Vitrified Tile Production By The Use of Borate Flux, Qualicer. Spain.

[4] MORENO A., GARCIA -TEN J., BOU E., GOZALBO A., 2000., Using Boron As an Auxiliary Flux in Porcelain Tile Compocitions, 77-91. Qualicer. Spain.

[5] TULYAGANOV, D.U., AGATHOPOULOS, S., FERNANDES, H.R., FERREIRA, J.M.F., 2005, Influence of Lithium Oxide as Auxiliary Flux on The Properties of Triaxial Porcelain Bodies. Journal of the European Ceramic Society, 26. 1131-1139.

[6] LOW.M., MATHEWS T., GARROD, T., ZHOU, T.,1997, Processing of spodumenemodified mullite ceramics, Journal of Materials Science, 32. 3807-3812

[7] YET, G., KARA, A. ,2007, Bor ve Türevlerinin Yer Karosu Çamur Reolojisi ve Sinterleme Davranışları Üzerine Etkileri. IV.Uluslararası Katılımlı Seramik, Cam, Emaye, Sır ve Boya Semineri, 505-520.

[8] ÇİĞDEMİR, G., KARA, A., KARA, F. ,2005, Porselen Karo Bünyelerine Borik Asit İlavesinin Etkileri.I. Ulusal Bor Çalıştayı, 19-24.

[9] TS EN 14411/Grup BIII. Su Emmesi E>10\% olan Kuru Preslenmiş Seramik Karolar, 2006.

[10] VILCHES, E.S., 2002, Technical Considerations on Porcelain Tile Products and Their Manufacturing Process, Volume 1. 57-83. Qualicer. Spain.

[11] IQBAL Y., LEE W.E., 2000, Microstructural Evolution in Triaxial Porcelain, J.Am. Ceram.Soc. 83[12]. 3121-27.

[12] EPPLER, R.A. ,1963, Glass Formation and Recrystallization in The Lithium Metasilicate Region of The System $\mathrm{Li}_{2} \mathrm{O}-\mathrm{Al}_{2} \mathrm{O}_{3}-\mathrm{SiO}_{2}$, Journal of the American Ceramic Society. 46(2): 100 .

[13] CARUS, L.A., BRAGANÇA, S.R. ,2013, Investigation of Spodumene-bearing Rock as a Flux for Bone China Production, Material Research 16(6). 1398-1404.

[14] KURAMA. S., KARA A., KURAMA H., 2007, Investigationnof Borax Waste Behaviour in The Wall Tile Production, Journal of European Ceramic Society. 27. 1715-1720.

[15] LOW, I. MATHEWS, E. GARROD, T., ZHOU, D., PHILIPS, D.N. and PILLAI, X.M., Processing of Spodumen-Modified Mullite Ceramics.,1997, J.Mater Sci. 32. 38173812.

[16] SIDNEI, J.G,S, JOSE N.F.,2003, Sintering Behavior of Porous Wall Tile Bodies During Fast Single-Firing Process. Materials Resarch, 8,197-200 